\title{
The Use of Calcium in Quails During Egg Hatching Phase by Adding Yacon Leaf Powder (Smallanthus sonchifolius)
}

\author{
Emerson Umbu Hemur Patangara1, Vitus Dwi Yunianto², \\ Bambang Sukamto ${ }^{2}$, and Lilik Krismiyanto ${ }^{2}$ \\ ${ }^{1}$ Student ofLivestock and AgriculturalFaculty of Universitas Diponegoro \\ ${ }^{2}$ Professor of Livestock and Agricultural Faculty of Universitas Diponegoro \\ Jl. Prof. Soedarto, Tembalang, Semarang \\ Coresponding author : Emerson.flats.37@gmail.com
}

\begin{abstract}
The goal of this research is to find out the use of calcium in quails during egg hatching phase by adding yacon leaf powder (Smallanthus sonchifolius). The subject used were 160 quail birds that are in the phase of hatching eggs at the age of 5 weeks, weighing 135,81 $\pm 3,25$ gr. The method of this research was Completely Randomized Design (CRD) with 5 treatments and 4 replication, every tested units consist of 8 birds. The treatment applied consist of $\mathrm{T} 0=$ basal ration, $\mathrm{T} 1=$ basal ration $+1 \%$ yacon leaf powder, $\mathrm{T} 2=$ basal ration $+2 \%$ yacon leaf powder, $\mathrm{T} 3=$ basal ration $+3 \%$ yacon leaf powder and $\mathrm{T} 4=$ basal ration $+4 \%$ yacon leaf powder. The parameter being measured includes the consumption of calcium, calcium's retention, weight of the shell, thickness of the shell and the production of the eggs. The data was analyzed by using Analysis of Variants (ANOVA) with a significance level of 5\% and if significantly affected it will continue with Duncan's Multiple Distance Test. The result shows that the significant effect of adding yacon leaf powder $(\mathrm{P}<0.05)$ on calcium's retention and the production of the eggs, but it did not affect $(\mathrm{P}>0.05)$ on the consumption of calcium, the weight of the shell and the thickness of the shell. In summary, by adding the yacon leaf powder until level $4 \%$ in ration, it may increase the use of egg calcium in quailduring egg hatching phase.
\end{abstract}

Key words: quail birds; yacon leaf powder; the use of egg calcium.

\section{Introduction}

Quail ( coturnix coturnix ) japonica is one of poultry commodities that have an important role and prospect to produce eggs. Quail can also be as gemak (Javanese) and quail is considered as wild bird. In Indonesia, quail started to be recognized and farmed since the late 1979. Quails havesmall and round body, and very short tail (Tumbilung. et al, 2014 ), with brown streaks on its feathers. The classifications are Kingdom: Animalia, Phylum: Chordata, Subfilum: Vertebrata, Class: Aves, Ordo: Galiformes, Family: Phasianidae, Sub Family: Perdicinae, Genus: Coturnix and Sub Spesies: Coturnixcoturnix japonica (Wuryadi, 2014).

Quail has its benefit, that is that they can grow and breed quickly. Female quail are able to become broody and breed at 6 weeks. The productivity of quail can reach up to 250 - 300 eggs/ year with an average weight of 10 gr/egg (Wuryadi, 2013). Average Quail Day Production in one population is ranging from $78-85 \%$ (Wuryadi, 2011). A 
decrease in egg production is affected by a number of factors, while age is one of them, it can also be affected by health and use of proteins as part of their diet. It can also be affected by health, rations quality and rations consumption (Saraswati et al., 2013).

Calcium is one of macro minerals that plays an important role in forming egg shells (Suprapto et al, 2012). Egg shells are composed of $94 \%$ calcium carbonate, $1 \%$ magnesium carbonate, $1 \%$ of calcium phosphate, and the remainder is $4 \%$ organic matter (Wulandari et all, 2012). An adequate consumption and calcium retention in quails during egg hatching phase can increase the quality and egg production. The thickness and the weight of egg shells is heavily related to consumption and calcium retention (Yuwanta, 2010)

Yacon is plant native to Andes highlands in South America. Yacon plant in Indonesia can also be referred as insulines. Yacon leaf or insulin leaf provides benefits as antioxidants source. Yacon leafhave active compounds such as flavonoid, tannine and polyphenol. Active compound in antioxidants plays a functional role as antioxidants to counteract free radicals that goes into digestive tract (Nurmawati and Wulandari, 2018). Based on the benefits of yacon leaf, than adding them to the rations of quails during egg hatching phase can increase use of calcium.

The goal of this research is to find out the use of calcium in quails during egg hatching phase by adding yacon leaf powder. The benefit of this research is to obtain information of the use of calcium in quails during egg hatching phase by adding yacon leaf powder

\section{Materials}

\section{Materials and Methods}

The subject used were 160 quail birds that are in the phase of hatching eggs at the age of 5 weeks, weighing 135,81 $\pm 3,25$ gr. The feed ingredient that was used in basal rations are composed of yellow maize, soybean residue, fish flour, $\mathrm{CaCO}_{3}$, hard seashell flour and premix, and also yacon leafs powder as presented on Table 1. The tool used was the scale, thermohygrometer, cage, lamp, bucket, grinder, dringing and eating instruments, and stationery.

Table 1. Ransum composition and Nutrient Content

\begin{tabular}{|c|c|c|c|c|c|}
\hline \multirow{2}{*}{ Bahan } & \multicolumn{5}{|c|}{ Treatment $(\%)$} \\
\hline & $\mathrm{T}^{1}$ & $\mathrm{~T} 1$ & $\mathrm{~T} 2$ & T3 & T4 \\
\hline Yellow corn & 42,7 & 42,7 & 42,7 & 42,7 & 42,7 \\
\hline Brand & 19,4 & 19,4 & 19,4 & 19,4 & 19,4 \\
\hline Soybean meal & 22,4 & 22,4 & 22,4 & 22,4 & 22,4 \\
\hline Fish powder & 10 & 10 & 10 & 10 & 10 \\
\hline $\mathrm{CaCO}_{3}$ & 1 & 1 & 1 & 1 & 1 \\
\hline Shellfish powder & 4 & 4 & 4 & 4 & 4 \\
\hline Premix & 0,5 & 0,5 & 0,5 & 0,5 & 0,5 \\
\hline Yacon leaves powder & 0 & 1 & 2 & 3 & 4 \\
\hline Total & 100 & 101 & 102 & 103 & 104 \\
\hline Content of nutrition: ${ }^{2}$ & & & & & \\
\hline
\end{tabular}




\begin{tabular}{|c|c|c|c|c|c|}
\hline Energi Metabolism 3 & 2801,48 & 2773,74 & 2746,55 & 2719,89 & 2693,73 \\
\hline Crude Protein ${ }^{4}$ & 19,20 & 19,01 & 18,83 & 18,64 & 18,46 \\
\hline Crude Ash ${ }^{4}$ & 2,93 & 2,90 & 2,88 & 2,85 & 2,74 \\
\hline Crude Fiber ${ }^{4}$ & 4,95 & 4,90 & 5,85 & 4,80 & 4,76 \\
\hline Calsium $^{4}$ & 3,12 & 3,09 & 3,06 & 3,03 & 3,00 \\
\hline Fosfor ${ }^{4}$ & 0,85 & 0,84 & 0,84 & 0,83 & 0,82 \\
\hline Metionin $^{5}$ & 0,43 & 0,43 & 0,42 & 0,42 & 0,42 \\
\hline $\operatorname{Lisin}^{5}$ & 1,26 & 1,25 & 1,24 & 1,23 & 1,21 \\
\hline $\operatorname{Arginin}^{5}$ & 1,39 & 1,38 & 1,36 & 1,35 & 1,34 \\
\hline $\begin{array}{l}{ }^{1} \text { Based } \\
{ }^{2} \text { Same i } \\
{ }^{3} \text { Based } \\
{ }^{4} \text { Based } \\
\text { Nutris } \\
{ }^{5} \text { Based }\end{array}$ & $\begin{array}{l}\text { Tetabolisn } \\
\text { on } 100 \% \text {. } \\
1967) \text {. } \\
\text { at analyze } \\
(2018) \text {. } \\
\text { RC (1994 }\end{array}$ & nd miner & n Labor & cium Ilmu & \\
\hline
\end{tabular}

\section{Study Design}

The study design used was a completely randomized design (CRD) with 5 treatments and 4 replications (each experimental unit contained 8 animals). Data from the study were carried out using Analysis of Variance (ANOVA), if it has a significant effect ( $\mathrm{p}<0.05$ ) then continued with Duncan's Multiple Distance Test (UJBD)

The order of treatments applied are as follows:

$\mathrm{T} 0=$ Basal rations

$\mathrm{T} 1=$ Basal ration + yacon leaf powder $1 \%$

$\mathrm{T} 2=$ Basal ration + yacon leaf powder $2 \%$

$\mathrm{T} 3=$ Basal ration + yacon leaf powder $3 \%$

$\mathrm{T} 4=$ Basal ration + yacon leaf powder $4 \%$

The research method consists of introduction, maintenance and data retrieval. Introduction includes making yacon leaf flour, ration formulation and cage making. The dried yaconleaves are stored and milled using a grinder until they are smooth. The prepared feed ingredients are then formulated into basal rations (Table 1). The cage is made of $3 \times 3 \mathrm{~m}$ in size and a multilevel cage is made of $50 \times 20 \mathrm{~cm}$ for 20 cage units. The cage is fumigated with lime water until it is evenly distributed throughout the floor and walls of the cage. After that, disinfectant is sprayed throughout the cage and the environment.

Maintenance is carried out for one month with rations given twice a day, morning and evening. The ration given consisted of basal rations and added yacon leaf flour as a feed treatment. Drinking is done by adlibitum. Every morning and afternoon, eggs are taken and the eggs are weighed. Temperatures are recorded every day, which is morning at 6.00, noon at 12.00, and afternoon at 18.00.

The parameters measured in this study were calcium consumption, calcium retention, shell weight, shell thickness and egg production. The total collection was carried out in the last week of maintenance for 4 days. The total collection stage was done by means of a ration combined with an indicator ( $\mathrm{Fe} 2 \mathrm{O} 3$ ) is given in the morning and a red excreta is observed. The red excreta is stored in the excreta shelter until the red excreta disappears. During the total collection the excreta is sprayed using $0.2 \mathrm{~N}$ 
$\mathrm{HCl}$ every 2 hours. Excretathat was stored then weighed and dried in the sun and was weighed again. Excreta that has been air dried has been tested for water and calcium in the Laboratory. Eggshell thickness was measured using a calipers and the shell weight was measured using analytical scales with accuracy of $0.01 \mathrm{~g}$. The calculation formula for calcium consumption and calcium retention based on Farida et al. (2017) as follows:

Calcium consumption $(\mathrm{g})=$ ration consumption $(\mathrm{g}) \mathrm{x}$ calcium level $(\%)$

Calcium retention $(\mathrm{g})=$ calcium consumption $(\mathrm{g})$ - amount of excreta calcium $(\mathrm{g})$

The calculation formula for Quail Day Production (QDP) based on Zahra et al. (2012):

Quail Day Production $(\%)=\frac{\text { total of eggs }}{\text { quails live }} \times 100 \%$

Data Analysis

Data was analyzed using Analysis of Varian (ANOVA) with significance level of $5 \%$ and if there is a real significance $(\mathrm{p}<0,05)$, then it Duncan Multiple Distance Test was done to find our the difference between treatments..

\section{Result and Discussion}

Tabel 2. Average of Calcium consumption, calcium retention, weight of shell, thickness of shell and dan Quail Day Production (QDP)

\begin{tabular}{lccccc}
\hline \multirow{2}{*}{ Parameter } & \multicolumn{5}{c}{ Treatment } \\
\cline { 2 - 6 } & T0 & T1 & T2 & T3 & T4 \\
\hline Calcium Consumption (g/ekor/hari & 0,53 & 0,49 & 0,54 & 0,53 & 0,57 \\
Calcium Retension (g) & $0,29^{\mathrm{b}}$ & $0,29^{\mathrm{b}}$ & $0,30^{\mathrm{b}}$ & $0,32^{\mathrm{ab}}$ & $0,37^{\mathrm{a}}$ \\
Weight of Sheell and of Shell $(\mathrm{g})$ & 0,96 & 0,98 & 0,98 & 0,99 & 1,02 \\
Thickness of Shell (mm) & 0,29 & 0,30 & 0,31 & 0,31 & 0,30 \\
& & & & & \\
QDP(\%) & $73,85^{\mathrm{bc}}$ & $72,32^{\mathrm{c}}$ & $73,55^{\mathrm{bc}}$ & $76,28^{\mathrm{ab}}$ & $76,79^{\mathrm{a}}$ \\
\hline
\end{tabular}

Superskrip on same row shows of different $(\mathrm{p}<0,05)$.

\section{Calcium Consumption}

The results of the study based on the Anova test showed that the addition of yacon leaf flour to the ration did not affect calcium consumption. The same results caused calcium levels in the ration from $\mathrm{T} 0$ to $\mathrm{T} 4$ did not experience a significant decrease. The antioxidant content in yacon leaf flour has not been able to increase calcium consumption. The results of the study from Syafitri et al. (2015) that the active ingredients of flavonoids or antioxidants in Beluntas leaf extract with a treatment level of $2 \%, 4 \%, 6 \%$ and $8 \%$ have not been able to contribute to the consumption of calcium rations. The results of the study from Santoso et al. (2016) that flavonoids or antioxidants play a greater role in reducing the formation of free radicals and counteracting free radicals.

\section{Calcium Retention (Ca)}

The results of the study based on the Anova test showed that the addition of yacon leaf flour to the ration could increase calcium retention. Increased calcium retention 
occurs at the level of $4 \%$ (T4) higher than level $0 \%$ (T0); $1 \%$ (T1) and 2\% (T2). The increased level of addition of yacon leaf flour has an impact on calcium absorption. The flavonoid content in yacon leaf flour can affect the digestive process in the small intestine. The role of flavonoids in the digestive tract is an antioxidant to counteract free radicals, increase the growth of microfolora in the intestine and facilitate the digestive system. Winarti (2010) states that flavonoids have the role of antioxidants which can improve the digestive system. Londok and Mandey (2014) reported that flavonoids that have the role of antioxidants have been shown to affect the dynamics of microflora in the digestive tract, optimizing the immune system of the intestine, which aids digestion and absorption of nutrients. Research results of Mentari et al. (2014) that antioxidants in key meeting flour with a treatment level of $1.6 \%-2 \%$ were able to increase calcium retention and calcium mass of meat in broler chickens. Tugiyanti et al. (2017) reported that flavonoids in breadfruit leaf flour with a treatment level of $1.5 \%$ were able to increase calcium retention in quails.

\section{Weight and Thickness of Shell}

The results showed that the addition of yacon leaf flour to the ration could increase the weight and thickness of the eggshell. The more addition of yacon leaf flour, the better the addition of weight and thickness of the eggshell. This shows that the administration of yacon leaf flour has no effect $(\mathrm{P}>0.05)$ on the weight and thickness of the shell. Although numerically, the addition of yacon leaf flour to a level of $4 \%$ in the ration increases the weight of the shell and the thickness of the shell. Setiawati et al. (2016) reported that shell weights and thickness were directly related to the availability of calcium during shell formation, because eggshells were formed from calcium and carbonate ions. Yuwanta (2010) that the higher the consumption and retention of calcium, the higher the weight and thickness of the eggshell . The results of the study of Tugiyanti et al. (2017) that flavonoids in breadfruit leaf flour with a treatment level of $1.5 \%$ can increase the weight and thickness of shells in quails.

\section{Quail Day Production(QDP)}

The results showed that addingyacon leaf flour with a level of $4 \%$ (T4) could increase QDP compared to levels of $1 \%$ and 2\% (Table 2). This shows that the addition of yacon leaf flour to the ration had a significant effect $(P<0.05)$ on quail egg production. The active ingredient in the form of flavonoids in yacon leaf flour as antioxidants can improve the health of microflora in the small intestine, facilitate the digestive system and help the process of retention of calcium thereby increasing egg production. Londok and Mandey (2014) that flavonoids that have the role of antioxidants are proven to affect the dynamics of microflora in the digestive tract, optimizing the intestinal immune system so that it helps the process of digestion and absorption of nutrients. The results of the study of Edi et al. (2018) that flavonoids in teak leaf extract were added to the $0.8 \%$ level of laying rations able to increase the population of microflora in the digestive tract, improve animal health and absorb nutrient rations and be able to increase egg production. Mahfudz et al. (2010) that livestock health also greatly affects the size of retention of nutrient rations. 


\section{Conclusion}

The addition of yacon leaf flour to a level of $4 \%$ in the ration can increase calcium utilization and egg production in the quail laying phase, even though calcium consumption, weight and eggshell are the same.

\section{References}

Edi, D. N., M. H. Natsir dan I. Djunaidi. 2018. Pengaruh penambahan ekstrak daun jati (Tectona grandis linn. $f$ ) dalam pakan terhadap performa ayam petelur. J. Nutrisi Ternak Tropis. $1: 34-44$.

Londok, J. J. M. R. dan J. S. Mandey. 2014. Potensi fitokimia dan aktivitas antimikroba daun sirsak (Annona muricata linn) sebagai kandidat bahan pakan ayam pedaging. J. LPPM Bidang Sains dan Teknologi. $1: 30-36$.

Mahfudz, L. D., T. A. Sarjana dan W. Sarengat. 2010. Efisiensi Penggunaan Protein Ransum yang Mengandung Limbah Distilasi Minuman Beralkohol (LDMB) oleh Burung Puyuh (Coturnix coturnix japonica) Jantan. Dalam: Prosiding Seminar Nasional Kebangkitan Peternakan. Fakultas Peternakan. Universitas Diponegoro. Hal. $887-894$.

Mentari, A. S., L. D. Mahfudz dan N. Suthma. 2014. Massa protein dan lemak daging pada ayam broiler yang diberi tepung temukunci (Boesenbergia pandurata roxb.) dalam ransum. Animal Agriculture Journal $3: 211$ - 220.

NRC. 1994. Nutrient Requirements of Beef Cattle. 9 th Revised Edition. National Academy Press, Washington, D.C.

Nurmawati, T. dan N. Wulandari. 2018. Efektivitas antara umbi dan daun tanaman yacon (Smallanthus sonchifolius) terhadap penurunan kadar gula darah tikus putih (Rattus norvegicus) yang terinduksi Streptozotocin. Strada J. Ilmiah Kesehatan. 7 : $63-68$.

Santoso, B., R. S. Utomo dan M. D. Wiyoga. 2016. Analisis hubungan senyawa golongan flavonoid dari 24 famili tanaman terhadap aktivitas penangkap radikalnya. Prosiding Seminar Nasional Kimia. Universitas Jenderal Achmad Yani - Himpunan Kimia Indonesia, Bandung, 3 - 4 Agustus 2016. Hlm 139 146.

Saraswati, T.R., W. Manalu, D. R. Ekastuti dan N. Kusumorini. 2013. Increased egg production of japanese quail (Cortunix japonica) by improving liver function through turmeric powder supplementation. International Journal of Poultry Science. 12 : $601-614$.

Setiawati, T., R. Afnan dan N.Ulupi. 2016. Performa produksi dan kualitas telur ayam petelur pada sistem litter dan cage dengan suhu kandang berbeda. J. Ilmu Produksi dan Teknologi Hasil Peternakan. 4 : 197-203. 
Syafitri, Y. E., V. D. Yunianto dan N. Suthama. 2015. Pemberian ekstrak daun beluntas (Pluchea indica less) dan klorin terhadap massa kalsium dan massa protein daging pada ayam broiler. Animal Agriculture Journal. 4 : 155 - 164.

Tugiyanti, E., Rosidi dan A. K. Anam. 2017. Pengaruh tepung daun sukun (Artocarpus altilis) terhadap produksi dan kualitas telur puyuh (Coturnix-coturnic japonica). Agripet. $17: 121-131$.

Winarti, S. 2010. Makanan Fungsional. Graha Ilmu. Yogyakarta.

Wulandari, E. C., W. Murningsih dan H. I. Wahyuni. 2012. Deposisi kalsium dan fosfor pada cangkang telur Ayam Arab dengan pemberian level Azolla micrphylla. Animal Agriculture Journal. $1: 507$ - 520.

Wuryadi, S. 2011. Buku Pintar Beternak dan Bisnis Puyuh. Agromedia Pustaka. Jakarta.

Wuryadi, S. 2013.Beternak Puyuh. Agromedia Pustaka. Jakarta.

Wuryadi,S. 2014. Buku Pintar Beternak dan Berbisnis Puyuh. Cetakan1. Agromedia Pustaka. Jakarta.

Yuwanta, T. 2010. Telur dan Kualitas Telur. UGM Press. Yogyakarta. 